\title{
SIMULASI CFD PEMBAKARAN OXY-FUEL PADA PACKAGE BOILER MENGGUNAKAN MODEL RADIASI DISCRETE ORDINATE
}

\author{
Willy Riansah ${ }^{1}$, Reza Setiawan ${ }^{2}$, Rizal Hanifi ${ }^{3}$ \\ ${ }^{1,2,3}$ Teknik Mesin, Universitang Singaperbangsa Karawang, Indonesia \\ ${ }^{1} 1610631150130 @$ student.unsika.ac.id
}

\begin{abstract}
ABSTRAK
Meningkatnya konsentrasi $\mathrm{CO}_{2}$ di atmosfer, mendorong umat manusia untuk melakukan penelitian tentang teknologi yang ramah lingkungan dan rendah emisi. Berbagai penelitian sudah dilakukan, salah satunya adalah pembakaran oxyfuel. Pembakaran oxy-fuel merupakan salah satu teknologi penangkapan dan penyimpanan karbon (CCS), dimana bahan bakar dibakar dengan campuran oksigen murni dan daur ulang gas buang. Perbedaan kondisi tersebut dapat mempengaruhi suhu pembakaran dan perpindahan panas radiasi pada ruang pembakaran. Oleh sebab itu, penelitian ini bertujuan untuk mengetahui perbandingan suhu pembakaran dan perpindahan panas radiasi yang terjadi di dalam ruang bakar antara pembakaran udara dan pembakaran oxy-fuel. Objek penelitian ini adalah sebuah package boilerberjenis water tube boilerdi salah satu unit pembangkit uap dengan kapasitas uap 100 ton/jam. Penelitian ini dilakukan dengan menggunakan simulasi CFD. Perpindahan panas radiasi dimodelkan dengan model radiasi Discrete Ordinate (DO) dan model Weighted Sum of Gray Gases (WSGG) yang digunakan untuk menghitung energi radiasi yang diserap dan dipancarkan oleh gas hasil pembakaran. Dari hasil simulasi CFD didapat bahwa suhu maksimum pembakaran pada pembakaran oxy-fuel yaitu sebesar $1.865,34^{\circ} \mathrm{C}$ lebih tinggi dari pembakaran udara yaitu sebesar $1.837,01^{\circ} \mathrm{C}$, begitupun dengan energi radiasi yang dipancarkan pada pembakaran oxy-fuel adalah sebesar 3,45 $\mathrm{MW} / \mathrm{m}^{2}$ lebih tinggi dari pembakaran udara yaitu $2,75 \mathrm{MW} / \mathrm{m}^{2}$.
\end{abstract}

Kata kunci: pembakaran oxy-fuel, package boiler, computational fluid dynamics, model radiasi discrete ordinate.

\section{ABSTRACT}

CFD Simulation of Oxy-fuel Combustion in Boiler Package Using Discrete Ordinate Radiation Model. The increasing concentration of $\mathrm{CO}_{2}$ in the atmosphere encourages humanity to research technology that is environmentally friendly and low in emissions. Various studies have been conducted, one of wich is the oxy-fuel combustion system. Oxy-fuel combustion is a carbon capture and storage (CCS) technology, where the fuel is a burned with a mixture of pure oxygen and recycled exhaust gases. The difference in these conditions can affect the combustion temperature and radiant heat transfer in the combustion chamber. Therefore, this study aims to compare the combustion temperature and radiant heat that occurs in the combustion chamber between the combustion system and the oxy-fuel combustion system. The object of this research is a package boiler with a water tube boiler type in a steam generator unit with a steam capacity of 100 tons/hour. This research was conducted using a CFD simulation. Radiation heat transfer is modelled with the Discrete Ordinate (DO) model radiation and the Weighted Sum of Gray Gases (WSGG) model is used to calculate the radiation energy absorbed and emitted by the combustion gases. From the CFD simulation results, it is found that the temperature of the combustion system in the oxy-fuel combustion system is $1,865.34^{\circ} \mathrm{C}$ higher than the air combustion system, which is $1,837.01^{\circ} \mathrm{C}$, as well as the radiation energy emitted in the oxy-fuel system is $3.45 \mathrm{MW} / \mathrm{m}^{2}$ is higher than the combustion air system which is $2.75 \mathrm{MW} / \mathrm{m}^{2}$.

Keywords: oxy-fuel combustion, package boiler, computational fluid dynamics, radiation, discrete ordinate radiation model. 


\section{PENDAHULUAN}

Pasokan energi yang efisien dan bersih merupakan salah satu kebutuhan yang mendasar bagi umat manusia. Saat ini, sistem pemasok energi kita sedang mengalami transisi jangka panjang dari bentuk konvensional ke gaya yang lebih rendah emisi, terutama dalam menangani emisi gas rumah kaca ke atmosfer. Menurut The Intergovermental Panel on Climate Change (IPCC) bahwa suhu global dan konsentrasi $\mathrm{CO}_{2}$ di atmosfer telah meningkat secara signifikan sejak permulaan evolusi industri [1]. Emisi $\mathrm{CO}_{2}$ tersebut berkontribusi dalam perubahan iklim, maka dari itu teknologi Carbon Capture and Storage (CCS) atau teknologi penangkapan dan penyimpanan karbon dapat membantu mengurangi emisi $\mathrm{CO}_{2}[2]$.

Teknik penangkapan $\mathrm{CO}_{2}$ sendiri secara umum dapat digolongkan menjadi tiga teknik, yaitu teknik penangkapan paska-pembakaran, pra-pembakaran, dan pembakaran oxy-fuel. Pembakaran oxy-fuel merupakan pembakaran yang menggunakan oksigen murni. Teknik pembakaran oxy-fuel dikembangkan untuk menghindari pengenceran oleh nitrogen dalam gas hasil pembakaran. Oksigen murni didapat dari proses pemisahan oksigen dari udara dalam sebuah Air Separation Unit (ASU). Namun, pembakaran dengan menggunakan oksigen murni dapat menyebabkan suhu pembakaran menjadi tinggi [3]. Gas buang hasil dari pembakaran oxy-fuel mengandung gas $\mathrm{CO}_{2}$ dan $\mathrm{H}_{2} \mathrm{O}$ dengan konsentrasi yang tinggi. Gas buang tersebut dapat didaur ulang ke dalam boiler [4]. Resilkulasi gas buang digunakan untuk menurunkan suhu pembakaran yang terlalu tinggi akibat pembakaran dengan oksigen murni dan juga mengisi volume $\mathrm{N}_{2}$ yang hilang untuk memastikan ada cukup gas yang membawa panas pada boiler. Pada akhirnya, menggunakan teknologi oxy-fuel dapat mengurangi emisi gas dan berpotensi menghilangkan 800 juta ton $\mathrm{CO}_{2}$ dari atmosfer setiap tahunnya [5].

Perbedaan kandungan oksigen antara pembakaran udara dan pembakaran oxy-fuel menyebabkan perbedaan suhu dan perpindahan panas radiasi yang terjadi pada ruang bakar. Namun ada keterbatasan pengalaman dalam penggunaan pembakaran oxy-fuel pada dunia industri, maka dari itu penggunaan metode numerik seperti Computational Fluid Dynamics (CFD) dapat membantu menyelesaikan masalah perpindahan panas di dalam boiler [6]. Banyak model yang telah dikembangkan untuk menyelesaikan masalah radiasi, model ini diterapkan untuk mensimulasikan perpindahan panas radiasi di dalam ruang bakar, yang sangat penting untuk memprediksi suhu pada pembakaran. Salah satu model tersebut adalah model radiasi Discrete Ordinate (DO), model ini sangat sering dipakai karena memiliki tingkat akurasi yang tinggi [7].

Penelitian mengenai pembakaran oxy-fuel sudah banyak dilakukan sebelumnya, dimulai dari Abraham pada tahun 1982 dalam kasus menyediakan gas buang yang akan $\mathrm{CO}_{2}$ untuk meningkatkan perolehan minyak [8], Buhre pada tahun 2005 tentang teknologi pembakaran oxy-fuel pada sistem pembangkit berbahan bakar batubara [9] yang dikembangkan kembali oleh Terry Wall pada tahun 2009 [4], Bohnstein pada tahun 2019 tentang simulasi CFD pada pembakaran oxy-fuel di sistem pembangkit dengan pengaplikasian model radiasi Wighted Sum of Gray Gases (WSGG) [6], Mingke Xie pada tahun 2020 tentang studi numerik untuk mengetahui karakteristik penyalaan otomatis dari pembakaran oxy-fuel dengan bahan bakar metana [10], dan masih banyak lagi.

Pada penelitian ini bertujuan untuk mengetahui perbandingan antara pembakaran udara dan pembakaran oxy-fuel dari parameter suhu pembakaran dan perpindahan panas radiasi yang terjadi di dalam ruang bakar. Pemodelan CFD dilakukan pada sebuah package boiler berbahan bakar gas alam dengan menggunakan gas $\mathrm{CO}_{2}$ sebagai refresentasi resilkulasi gas buang pada pembakaran oxy-fuel. Rasio $21 \% \mathrm{O}_{2}$ dan $79 \% \mathrm{CO}_{2}$ ditetapkan sebagai representasi kondisi pembakaran oxy-fuel, dan rasio $21 \% \quad \mathrm{O}_{2}$ dan $79 \% \quad \mathrm{~N}_{2}$ sebagai pembakaran udara. Perpindahan panas radiasi dimodelkan dengan model Discrete Ordinate (DO), dan model Weighted Sum of Gray Gases (WSGG) digunakan untuk menghitung energi radiasi yang diserap dan dipancarkan oleh gas hasil pembakaran.

\section{METODE}

Metode yang digunakan pada penelitian ini adalah metode komparatif yaitu membandingkan suhu pembakaran dan perpindahan panas radiasi pada package boiler dengan menggunakan pembakaran udara dan pembakaran oxy-fuel. 


\section{Diagram Alir Penelitian}

Langkah awal dalam melakukan penelitian ini adalah mengidentifikasi permasalahan di lapangan, selanjutnya mempersiapkan studi literatur yang diperlukan untuk mengetahui data-data yang dibutuhkan dalam penelitian. Setelah data terkumpul, dilakukanlah simulasi pada salah satu perangkat lunak CFD yaitu ANSYS Fluent. Pertama lakukan simulasi pada kondisi pembakaran udara dengan menggunakan ukuran mesh/grid yang berbeda-beda untuk proses verifikasi, lalu suhu pembakaran hasil dari simulasi tersebut dibandingkan dengan suhu pembakaran pada data seet boiler untuk proses validasi dengan syarat perbedaan persentase maksimum 2\% [11]. Setelah proses verifikasi dan validasi seselai, lakukan simulasi dengan menggunakan kondisi pembakaran oxy-fuel, lalu bandingkan antara hasil simulasi pembakaran udara dan pembakaran oxy-fuel.

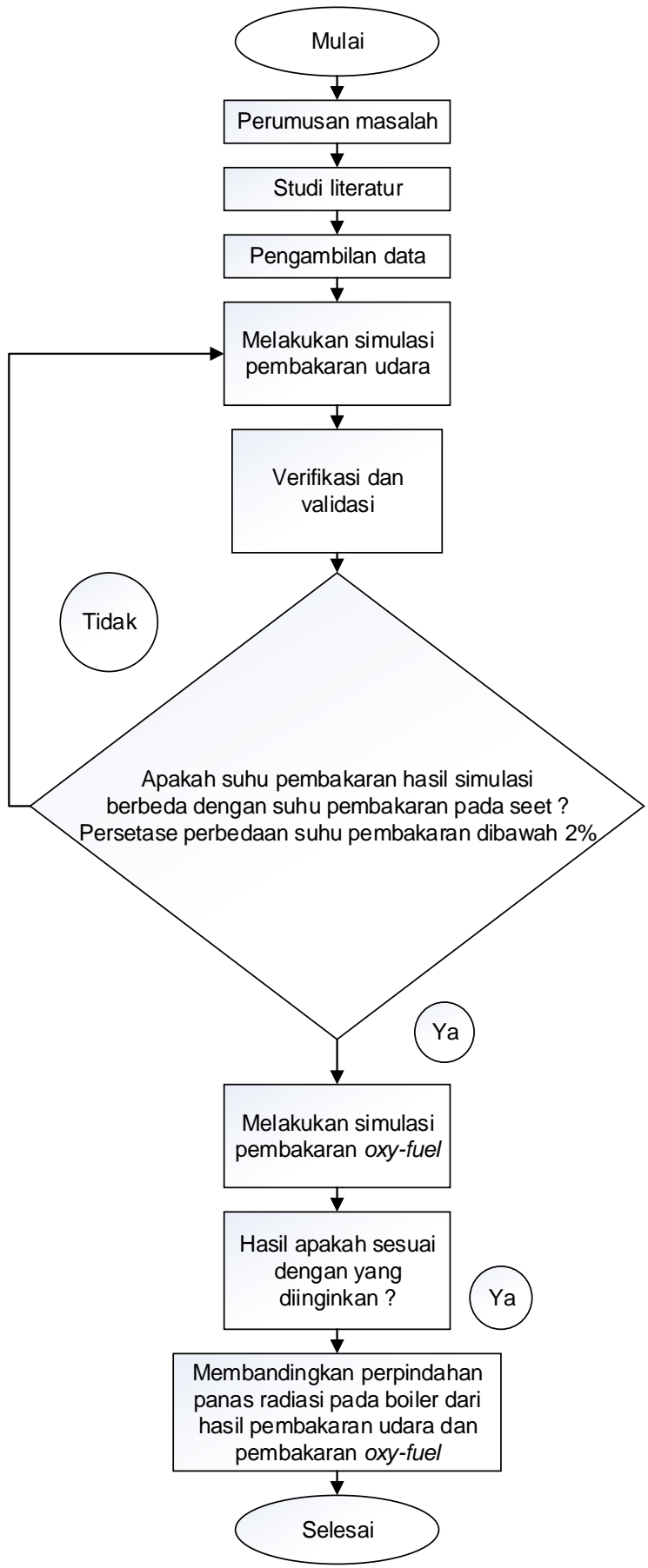

Gambar 1. Diagram alir penelitian

\section{Objek Penelitian}

Objek pada penelitian ini adalah sebuah package boiler berjenis water tube boiler di salah satu unit pembangkit uap di Pt. XYZ. Package boiler ini berkapasitas 100 ton/jam dan memiliki ukuran tinggi $9,875 \mathrm{~m}$, panjang $10,674 \mathrm{~m}$, lebar $5,968 \mathrm{~m}$. Boiler ini memiliki dua buah burner, dimana pada masing- 
masing burner terdapat bagian tempat masuknya udara primer, sekunder, dan bahan bakar selaku syarat untuk terjadinya proses pembakaran. Setelah memasuki burner, udara dan bahan bakar akan tercampur dengan api dari pemantik, dan terjadilah proses pembakaran. Pembakaran tersebut digunakan untuk memanaskan rangkaian pipa-pipa berbentuk dinding yang terdiri dari beberapa bagian, yaitu boiler tube, furnace header, rise pipe, feeder pipe, dan down comer. Di dalam pipa-pipa tersebut terdapat aliran air yang berasal dari water drum, yang nantinya akan diubah menjadi uap atau steam yang akan dimasukkan ke dalam steam drum. Berikut adalah desain dari package boiler tersebut:

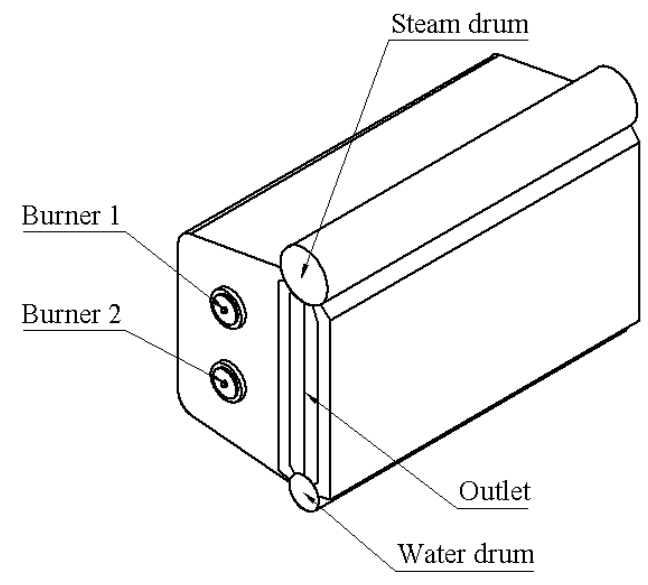

Gambar 2. Desain dan bagian intipackage boiler

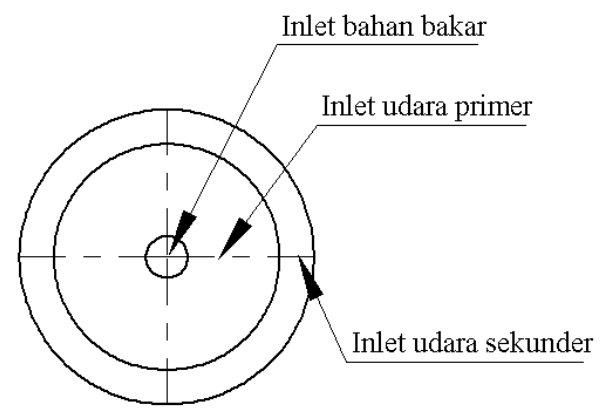

Gambar 3. Bagian-bagian pada burner

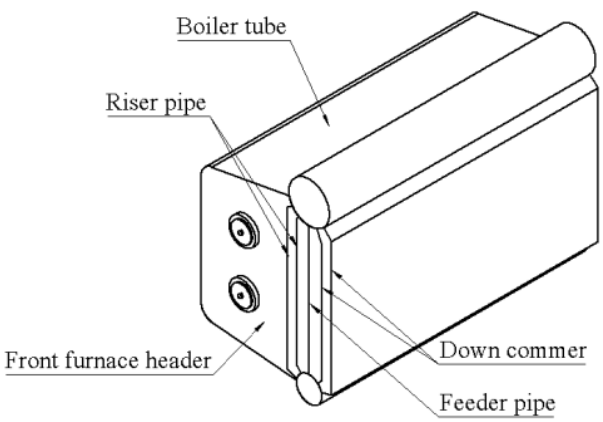

(a)

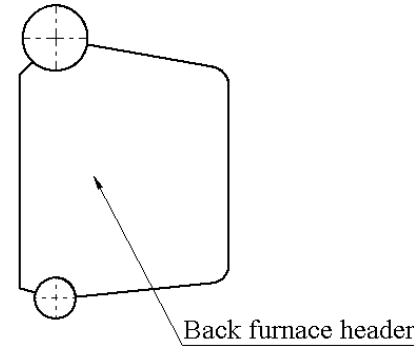

(b)

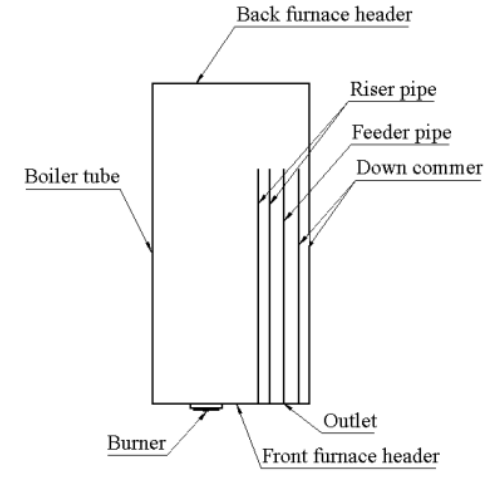

(c)

Gambar 4. Bagian dinding-dinding pipa pada boiler (a) tampak isometric (b) tampak belakang (c) tampak atas 
Parameter-parameter yang digunaan untuk kondisi batas simulasi pada setiap burnernya ditunjukkan pada tabel 1.

Tabel 1. Parameter kondisi batas simulasi.

\begin{tabular}{c|c|c|c}
\hline $\begin{array}{c}\text { Bagian inlet } \\
\text { pada setiap } \\
\text { burner }\end{array}$ & $\begin{array}{c}\text { Mass flow } \\
(\mathrm{kg} / \mathrm{s})\end{array}$ & $\begin{array}{c}\text { Tekanan } \\
(\mathrm{kPa})\end{array}$ & $\begin{array}{c}\mathrm{Suhu} \\
\left({ }^{\circ} \mathrm{C}\right)\end{array}$ \\
\hline $\begin{array}{c}\text { Inlet } \text { udara } \\
\text { primer }\end{array}$ & $5,482 \mathrm{~kg} / \mathrm{s}$ & $4,95 \mathrm{kPa}$ & $35^{\circ} \mathrm{C}$ \\
$\begin{array}{c}\text { Inlet } \text { udara } \\
\text { sekunder } \\
\text { Bahan bakar } \\
\text { (gas alam) }\end{array}$ & $10,181 \mathrm{~kg} / \mathrm{s}$ & $4,95 \mathrm{kPa}$ & $35^{\circ} \mathrm{C}$ \\
\hline
\end{tabular}

Package boiler menggunakan bahan bakar gas alam yang memiliki kandungan seperti pada tabel 2 .

Tabel 2. Kandungan pada gas alam.

\begin{tabular}{c|c}
\hline Komponen & Volume desain (\%) \\
\hline $\mathrm{CO}_{2}$ & $1,83 \%$ \\
$\mathrm{~N}_{2}$ & $2,54 \%$ \\
$\mathrm{CH}_{4}$ & $91,05 \%$ \\
$\mathrm{C}_{2} \mathrm{H}_{6}$ & $2,88 \%$ \\
$\mathrm{C}_{3} \mathrm{H}_{8}$ & $1,01 \%$ \\
\hline
\end{tabular}

Simulasi ini dibagi menjadi dua jenis kondisi pembakaran, yaitu:

1. Simulasi dengan menggunakan kondisi pembakaran udara, dimana kandungan pada udara yaitu $21 \% \mathrm{O}_{2}$ dan $79 \% \mathrm{~N}_{2}$

2. Simulasi dengan menggunakan kondisi pembakaran oxy-fuel, dimana kandungan pada udara yaitu $21 \% \mathrm{O}_{2}$ dan $79 \% \mathrm{CO}_{2}$

\section{Metode Pendekatan Model CFD}

Simulasi numerik untuk pembakaran udara dan pembakaran oxy-fuel dalam CFD digunakan untuk menyelesaikan perpindahan panas radiasi. Pada simulasi numerik ini menggunakan pendekatan finite-volume (FV) untuk aliran satu fasa, yaitu gas [12]. Berikut adalah persamaan dan model yang diselesaikan pada simulasi:

\section{Model turbulen}

Model k- $\varepsilon$ merupakan model turbulen yang sering dipakai dalam pengaplikasian Fluentkarena hasil prediksi yang mendekati kondisi nyata [13]. Model realizible $\mathrm{k}-\varepsilon$ dapat dijelaskan pada persamaan berikut [14]:

- Untuk k:

$$
\begin{aligned}
& \frac{\partial}{\partial t}(\rho k)+\frac{\partial}{\partial x_{j}}\left(\rho k u_{j}\right)= \frac{\partial}{\partial x_{j}}[ \\
& {\left.\left[\mu \frac{\mu_{t}}{\sigma_{k}}\right) \frac{\partial_{k}}{\partial x_{j}}\right]+ } \\
& G_{k}+G_{b}-\rho \varepsilon- \\
& Y_{M}+S_{k}
\end{aligned}
$$

- Untuk $\varepsilon$ :

$\frac{\partial}{\partial t}(\rho \varepsilon)+\frac{\partial}{\partial x_{j}}\left(\rho \varepsilon u_{j}\right)$

$=\frac{\partial}{\partial x_{j}}\left[\left(\mu \frac{\mu_{t}}{\sigma_{\varepsilon}}\right) \frac{\partial_{\varepsilon}}{\partial x_{j}}\right]$

$$
\begin{array}{ll}
+ & \rho C_{1} S_{\varepsilon}-\rho C_{2} \frac{\varepsilon^{2}}{k+\sqrt{v \varepsilon}} \\
+ & C_{1 \varepsilon} \frac{\varepsilon}{k} C_{3 \varepsilon} G_{b}+S_{\varepsilon}
\end{array}
$$

Dimana, $G_{k}$ adalah pembangkitan energi kinetik turbulensi karena perbedaan kecepata rata-rata, $G_{b}$ adalah generasi energi kinetik turbulensi dari gaya apung. $Y_{M}$ adalah kontribusi fluktuasu dalam turbulensi kompresibel terhadap laju disipasi keseluruhan $\sigma_{k}$ dan $\sigma_{\varepsilon}$ adalah bilangan prandalt untuk $k$ dan $\varepsilon$.

\section{Model pembakaran}

Pembakaran yang terjadi di dalam tungku pembakaran adalah pembakaran metana sempurna, dimana memiliki persaan kimia sebagai berikut [15]:

$\mathrm{CH}_{4}+2 \mathrm{O}_{2} \rightarrow \mathrm{CO}_{2}+2 \mathrm{H}_{2} \mathrm{O}$

Pada aplikasi Fluentterdapat beberapa pendekatan dalam pemodelan reaksi kimia dalam gas, salah satunya model species transport dan finite-rate chemistry. Model ini, didasarkan pada solusi persamaan transpor untuk fraksi massa spesies dengan mekanisme rekasi kimia. Pada model ini, Fluentmenghitung dengan nilai rata-rata dari spesies tersebut, dan dijelaskan dengan persamaan berikut [14]:

$\frac{\partial}{\partial t}\left(\rho Y_{i}\right)+\nabla \cdot\left(\rho \vec{v} Y_{i}\right)=-\nabla \cdot \vec{J}_{i}+R_{i}+S_{i}$

Dimana $\rho$ adalah massa jenis, $\vec{v}$ adalah kecepata rata-rata. Pada sisi sebelah kanan, $R_{i}$ adalah besar 
laju produksi spesies $i$ melalui reaksi kimia, dan $S_{i}$ adalah besar laju peningkatan produksi fasa yang terdistribusi.

\section{Radiative Transfer Equation (RTE)}

Radiative Transfer Equation (RTE) adalah suatu persamaan yang digunakan untuk mencari variabel intensitas radiasi. Dalam RTE, intensitas radiasi disimbolkan dengan $I$. Intensitas radiasi dalam persamaan ini merupakaan fungsi koordinat spasial $\vec{r}$ dan $\vec{s}$. Fungsi $\vec{r}=(x, y, z)$ adalah posisi pada ruang media gas, dan fungsi $\vec{s}=\left(S_{x}, S_{y}, S_{z}\right)$ adalah arah sinar radiasi. Dalam persamaan RTE terdapat persamaan laju perubahan, penyerapan, emisi, dan penghamburan intensitas radiasi. Persamaan RTE dapat dituliskan sebagi berikut [14]:

$$
\begin{aligned}
& \frac{d I(\vec{r}, \vec{s})}{d s}+\left(\alpha+\sigma_{S}\right) I(\vec{r}, \vec{s}) \\
& =\alpha n^{2} \frac{\sigma T^{4}}{\pi} \\
& +\quad \frac{\sigma_{S}}{4 \pi} \int_{0}^{4 \pi} I(\vec{r}, \vec{s}) \Phi\left(\vec{s} . \vec{s}^{\prime}\right) d \Omega^{\prime}
\end{aligned}
$$

Dimana:

$$
\begin{array}{ll}
\overrightarrow{\boldsymbol{r}} & =\text { Posisi vector } \\
\overrightarrow{\boldsymbol{s}} & =\text { Arah vector } \\
\overrightarrow{\boldsymbol{s}}^{\prime} & =\text { Vektor arah penghamburan } \\
\boldsymbol{S} & =\text { Panjang jalur } \\
\boldsymbol{\alpha} & =\text { Koefisien absorpsi dari gas }\left(\mathrm{m}^{-1}\right) \\
\boldsymbol{n} & =\text { Indeks bias dari gas } \\
\boldsymbol{\sigma}_{\boldsymbol{S}} & =\text { Koefisien penghamburan dari gas }\left(\mathrm{m}^{-1}\right) \\
\boldsymbol{\sigma} & =\text { Konstanta Stefan-Boltzman } \\
\left(5,669 \times 10^{-8} \mathrm{~W} / \mathrm{m}^{2} \cdot \mathrm{K}^{4}\right) & \\
\boldsymbol{I} & =\text { Intensitas radiasi } \\
\boldsymbol{T} & =\text { suhu lokal }\left({ }^{\circ} \mathrm{C}\right) \\
\boldsymbol{\Phi} & =\text { Fungsi fasa } \\
\boldsymbol{\Omega}^{\prime} & =\text { Kontrol sudut ruang }(\mathrm{sr})
\end{array}
$$

\section{Model radiasi Discrete Ordinates (DO)}

Perpindahan panas secara radiasi dimodelkan dengan menggunakan model radiasi discrete ordinate (DO). Model DO tersebut digunakan untuk memprediksi dengan baik suhu dari pembakaran. Model radiasi DO adalah model yang bekerja dengan cara memecahkan RTE pada setiap sudut ruang yang telah didiskretisasi. Model DO padaFluent menggunakan pendekatan finite-volume (FV). Pada Fluent, pemisahan sudut menggunakan oktan, dimana satu oktan adalah sebesar 1/8 dari $360^{\circ}$. Setiap oktan di lokasi spasial mana pun diatur menjadi sudut kontrol $\left(N_{\theta} \times N_{\phi}\right)$. Theta divisions $\left(N_{\theta}\right)$ dan phi divisions $\left(N_{\phi}\right)$ akan menentukan jumlah sudut kontrol yang digunakan untuk membedakan setiap oktan. Dalam menyelesaikan satu persamaan RTE pada arah sinar $\vec{s}$, maka persamaan RTE harus dihitung pada masing-masing arah sinar $\vec{s}[14]$. Pada penelitian ini, diskritisasi sudut pada model radiasi DO diatur secara default yaitu sebesar $2 \times 2$, masing masing 2 untuk theta divisions $\left(N_{\theta}\right)$ dan pjhi divisions $\left(N_{\phi}\right)$. Untuk pikselisasi juga diatur secara default yaitu sebesar $2 \times 2$, masing-masing 1 untuk theta pixels dan phi pixels. Pikselisasi dan diskritisasi sudut diatur secara default dikarenakan untuk mencegah beban komputasi yang terlalu tinggi dan waktu komputasi yang terlalu lama[14].

\section{Model Weighted Sum of Gray Gasses (WSGG)}

Setiap proses pembakaran menghasilkan gas pembakaran seperti uap air $\left(\mathrm{H}_{2} \mathrm{O}\right)$ dan $\mathrm{CO}_{2}$. Gas-gas ini tidak menyebarkan radiasi secara signifikan, tetapi merupakan penyerap dan pemancar energi radiasi yang sangat kuat. Akibatnya, variasi sifat radiasi terutama untuk $\mathrm{H}_{2} \mathrm{O}$ dan $\mathrm{CO}_{2}$, perlu diperhitungkan dengan tepat. Karakteristik absorpsi dan emisi dari masing-masing spesies kimia diasumsikan dengan menggunakan sebuah model, salah satunya adalah model Weighted Sum of Gray Gases (WSGG). Pada model ini, total absorptivitas dan emisivitas diasumsikan dengan jumlah emisivitas gas "abu-abu" dengan pertimbangan suhu. Total emisivitas pada gas campuran di jarak $\overrightarrow{\boldsymbol{s}}$ dapat dirumuskan sebagai berikut [14]:

$$
\varepsilon=\sum_{i=0}^{I} a_{\varepsilon, i}(T)\left(1-e^{-k_{i} p s}\right)
$$

Dimana, $a_{\varepsilon, i}$ adalah bobot faktor emisivitas untuk gas bau-abu $i$ berdasarkan suhu gas, $k_{i}$ adalah koefisien absorpsi pada gas abu-abu $i, p$ adalah tekanan parsial dari semua gas penyerap dan $s$ adalah panjang jalur. Bobot faktor emisivitas $a_{\varepsilon, i}$ dapat diartikan sebagai jumlah pecahan energi benda hitam di daerah spektral dimana terdapat koefisien ga $k_{i}$. Pada penelitian ini, model WSGG digunakan untk menghitung penyerapan dan emisivitas pada gas campuran hasil pembakaran dengan baik. 


\section{HASIL DAN PEMBAHASAN}

\section{Suhu Pembakaran}

Dari hasil simulasi CFD didapat bahwa suhu maksimum pada pembakaran oxy-fuel adalah sebesar $1.865,34^{\circ} \mathrm{C}$ lebih tinggi dari suhu maksimum pada pembakaran udara yaitu sebesar $1.837,01^{\circ} \mathrm{C}$, dapat dilihat pada gambar contour suhu hasil simulasi CFD pada gambar 5. Kurva pada gambar 6 menunjukkan perbedaan distribusi suhu pada pembakaran udara dan oxy-fuel dari burner 1 dan burner 2.Dari kedua kurva dapat dilihat bahwa pada jarak dari masing-masing burner, distribusi suhu
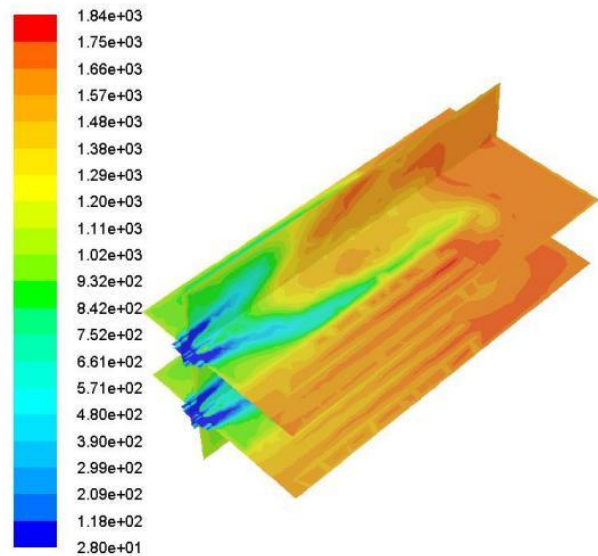

(a) pembakaran oxy-fuel lebih tinggi daripada pembakaran udara biasa. Perbedaan suhu tersebut dipengaruhi oleh tidak adanya kandungan $\mathrm{N}_{2}$ pada pembakaran oxy-fuel yang menyebabkan suhu menjadi lebih tinggi dibandingkan suhu pembakaran udara, namun dengan dominannya kandungan $\mathrm{CO}_{2}$ dari resilkulasi gas buang pada pembakaran oxy-fuel, suhu pembakaran menjadi tidak terlalu tinggi, hal tersebut sesuai dengan penelitian sebelumnya dimana resilkulasi gas buang digunakan untuk menurunkan suhu pembakaran yang terlalu tinggi akibat pembakaran dengan oksigen murni dan juga mengisi volume $\mathrm{N}_{2}$ yang hilang untuk memastikan cukupnya gas yang membawa panas pada boiler [3].
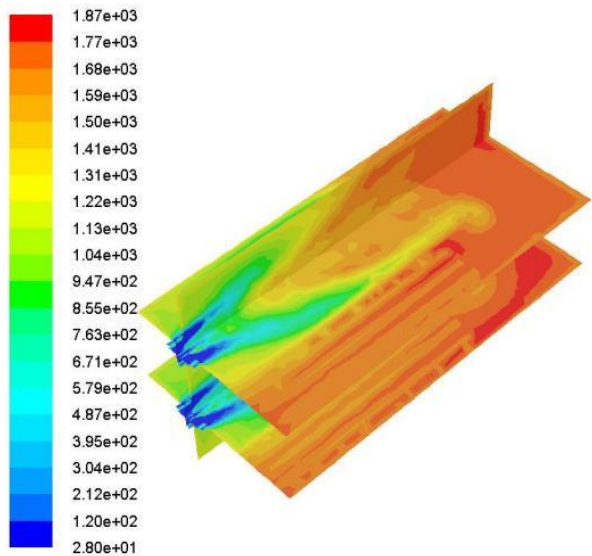

(b)

Gambar 5. Contour suhu pada pembakaran (a) pembakaran udara (b) pembakaran oxy-fuel

Distribusi suhu pembakaran pada jarak dari burner 1

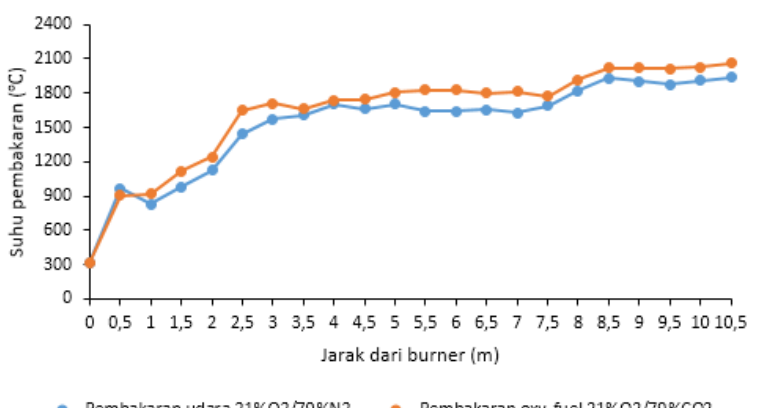

(a)
Distribusi suhu pembakaran pada jarak dari burner 2

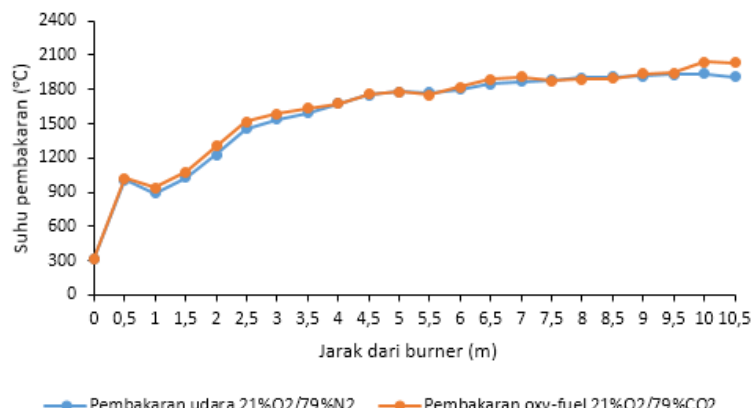

(b)

Gambar 6. Grafik perbandingan suhu pada jarak dari burner (a) burner 1 (b) burner 2

\section{Incident Radiation}

Incident radiation merupakan jumlah total perpindahan energi radiasi yang berada di dalam ruang pembakaran yang berasal dari api pembakaran. Dari hasil simulasi CFD didapat bahwa incident radiation maksimum yang ada pada pembakaran udara adalah sebesar $2,75 \mathrm{MW} / \mathrm{m}^{2}$ lebih kecil daripada pembakaran oxy-fuel yaitu sebesar $3,45 \mathrm{MW} / \mathrm{m}^{2}$. Dapat dilihat pada gambar 7 yang menunjukkan contour penyebaran energi radiasi maksimum pada masing-masing pembakaran. 


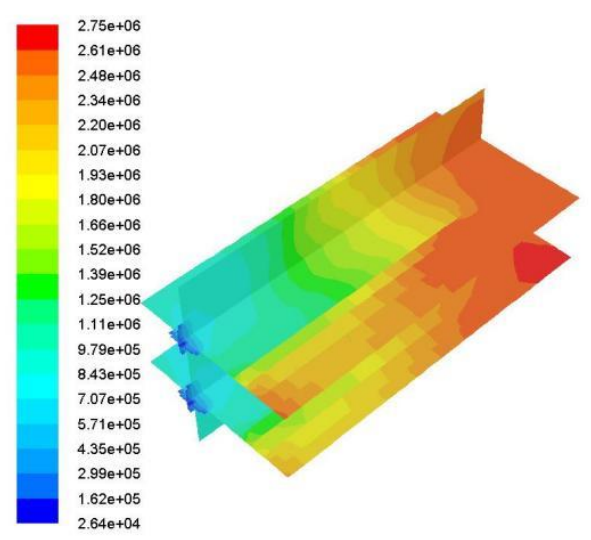

(a)
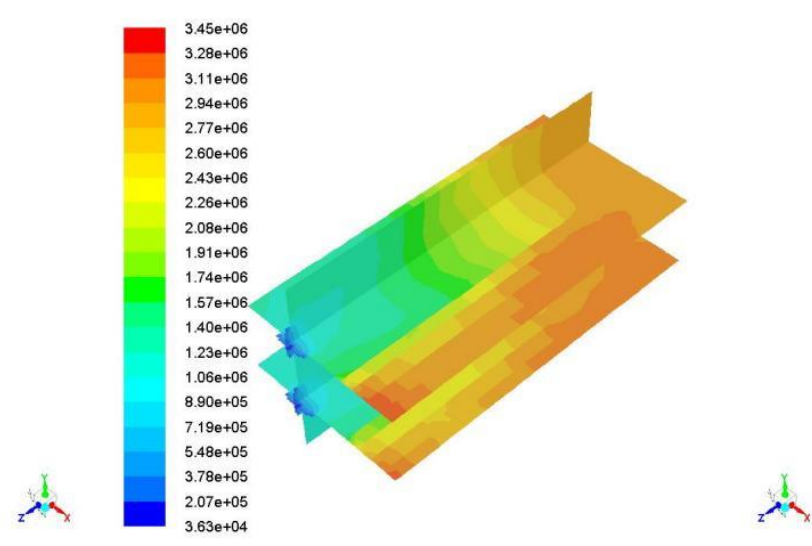

(b)

Gambar 7. Contourincident radiation (a) pembakaran udara (b) pembakaran oxy-fuel

\section{Energi Radiasi yang Diterima Dinding}

Ruang bakar pada boiler dikelilingi oleh pipa-pipa yang berisi aliran air yang dirubah menjadi uap, pipa-pipa tersebut berbentuk seperti dinding, maka dari itu sangat penting untuk mengetahui berapa besar energi radiasi yang diterima oleh dindingdinding pipa tersebut dari pembakaran. Karena semakin besar energi radiasi yang diterima maka semakin besar juga suhu pada pipa-pipa tersebut

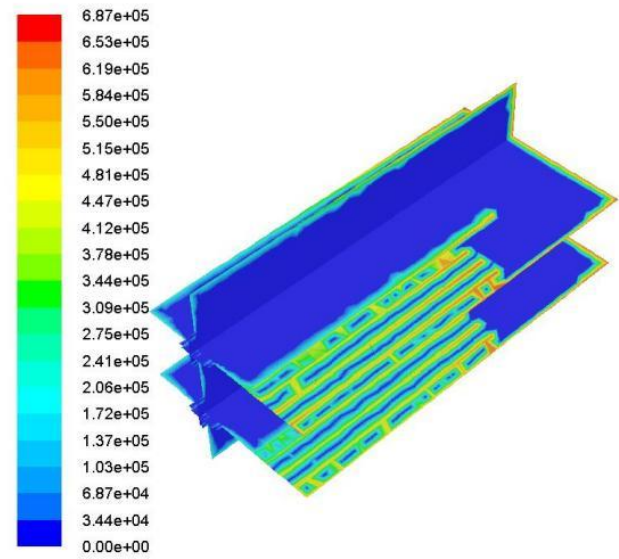

(a) yang nantinya akan berppengaruh pada proses perpindahan panas konduksi dan konveksi. Dari hasil simulasi CFD didapat bahwa energi radiasi maksimal yang diterima oleh dinding-dinding pipa pada pembakaran oxy-fuel adalah sebesar 849,33 $\mathrm{kW} / \mathrm{m}^{2}$ lebih besar dari pembakaran udara yaitu sebesar $687,25 \mathrm{~kW} / \mathrm{m}^{2}$, dapat dilihat pada gambar 8 yang menunjukkan contour energi radiasi yang diterima oleh dinding dinding pipa pada boiler tersebut.
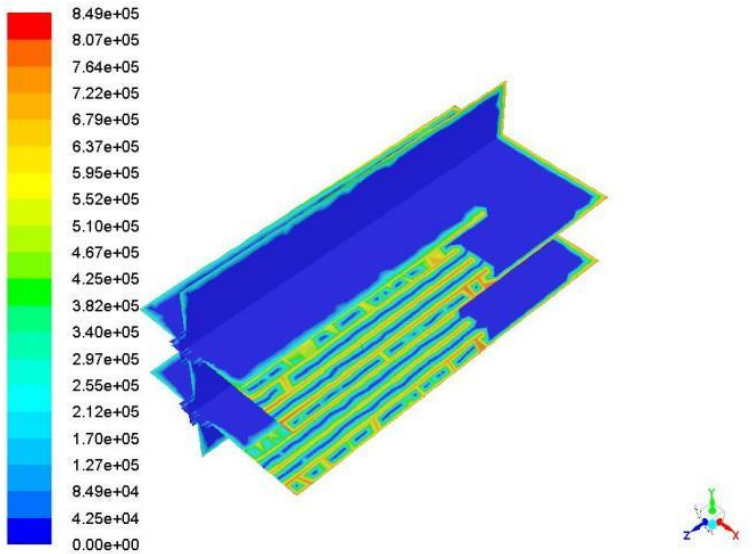

(b)

Gambar 8. Contourenergi radiasi yang diterima oleh dinding (a) pembakaran udara (b) pembakaran oxy-fuel

\section{KESIMPULAN}

Hasil simulasi CFD menunjukkan bahwa suhu maksimum pembakaran pada kondisi oxy-fuel lebih besar dibandingkan pada kondisi pembakara udara. Hal tersebut disebabkan oleh perbedaan sifat fisik gas antara kondisi pembakaran udara yang didominasi oleh $\mathrm{N}_{2}$ dan kondisi pembakaran oxy-fuel dengan $\mathrm{CO}_{2}$. Selain itu juga dapat mempengaruhi perpindahan panas radiasi, dapat dilihat bahwa energi radiasi maksimum yang dipancarkan pada pembakaran oxy-fuel lebih tinggi dibandingkan pembakaran udara, sehingga menyebabkan pipa-pipa 
aliran air yang berupa dinding di boiler pada pembakaran oxy-fuel menerima energi radiasi lebih tinggi dibandingkan pada pembakaran udara.

\section{DAFTAR PUSTAKA}

[1] IPCC . (2008). Contribution of working groups I, II and III to the fourth assessment report of the intergovernmental panel on climate change. Intergovernmental Panel on Climate Change

[2] S. Black, J. Szuhánszki, A. Pranzitelli, L. Ma, P.J. Stanger, D.B. Ingham, \& M. Pourkasha. (2013). Effects of firing coal and biomass under oxy-fuel conditions in a power plant boiler using CFD modelling. Fuel, 113, 780-786.

[3] Dr. Cahyadi, Dr. S.D. Sumbogo Murti, Dwika Budianto, ST,MT., Ir. Hari Yurismono, MEng.Sc, Toorsilo Hartadi, MSc.EE, Darmawan, MSc., . . . Prof. Dr.Ir. Adi surjosatyo, MSc. (2015). PLTU Batu Bara Superkritikal yang Efisien. Tanggerang Selatan: Balai Besar Teknologi Energi, BPPT.

[4] Terry Wall, Yinghui Liu, Chris Spero, Liza Elliot, Sameer Khare, Renu Rathnam,... . Jianglong Yu. (2009). An overview on oxyfuel coal combustion-state of the art research and technology development. Chemical Engineering Research and Design, 87, 10031016.

[5] EP. EU Zero Emissions platform. (2012). Biomass with $\mathrm{CO} 2$ capture and storage. The Way forward for Europe.

[6] Bohnstein, M. v., Ströhle, J., \& Epple, B. (2019). CFD Simulation of an Oxy-fuel Demonstration Power Plant with Application of a WSGG radiation model. Energy Procedia, 158, 1993-1998.

[7] Coelho, P. J. (2014). Advances in the discrete ordinates and finite volume methods for the solution of radiative heat transfer problems in participating media. Journal of Quantitative Spectroscopy \& Radiative Transfer, 145, 121146.
[8] Abraham, B.M., Asbury, J.G, Lynch, E.P., \& Teotia, A.P.S. (1982). Oil \& gas journal, 80, 68-70.

[9] B.J.P. Buhre , L.K. Elliott, C.D. Sheng, R.P. Gupta, \& T.F. Wall. (2005). Oxy-fuel combustion technology for coal-fired power generation. Progress in Energy and Combustion Science, 31, 283-307.

[10] Mingke Xie, Jianqin Fu, Yongxiang Zhang, Jingping Liu, \& Banglin Deng. (2020). Numerical study on the auto-ignition characteristics of methane oxy-fuel combustion highly diluted by $\mathrm{CO} 2$. Journal of the Taiwan Institute of Chemical Engineers, 114, 176-185.

[11] B. Vink, J. Schot, G. Vaz, \& S. Toxopeus. (2017). A Verification and Validation Study of CFD Simulations for the Flow Around a Tug. $1-6$.

[12] Hoi, P. C. (2017). Validation of discrete ordinate radiation model for application in $U V$ air disinfection Modeling. Lakehead University, Thunder Bay, Ontario, Canada: ProQuest LLC.

[13] Dwika budianto, Cahyadi, Adi Surjosatyo, \& Yulianto S. Nugroho. (2014). Prediksi karakteristik pembakaran oxy-fuel dengan pemodelan CFD.

[14] ANSYS, I. (2013). ANSYS Fluent Theory Guide.

[15] Milada KOZUBKOVÁ, Jaroslav KRUTIL, Marian BOJKO, \& Václav NEVRLÝ. (2012). Mathematical modeling of methane combustion. 22 - 26. 